\title{
HEALTH BEHAVIORS OF AMATEUR MOUNTAIN BIKE ATHLETES
}

original paper

(1) University School of Physical Education in Wroclaw

DOI: https://doi.org/10.5114/hm.2018.74060

\author{
MAGDALENA GRUSZCZYNSKA ${ }^{1}$, MONIKA BAK-SOSNOWSKA ${ }^{1}$, RYSZARD PLINTA ${ }^{2}$ \\ ${ }^{1}$ Department of Psychology, School of Health Sciences in Katowice, Chair of Social Sciences and Humanities, \\ Medical University of Silesia, Katowice, Poland \\ ${ }^{2}$ Department of Adapted Physical Activity and Sport, School of Health Sciences in Katowice, \\ Medical University of Silesia, Katowice, Poland
}

\begin{abstract} ( $p=0.031)$, and time devoted to training $(p=0.003)$.

Key words: health behaviors, mountain biking, amateur sports

\section{Introduction}

Health behaviors encompass all behaviors (or lack thereof) having an impact on human health and wellbeing. D. Gochman rates the following as health behaviors: beliefs, expectations, predictions, motives, thinking, emotional mechanisms of personality, and internal patterns of behavior connected with maintaining, enhancing and restoring health [1]. Among health behaviors, we may distinguish behaviors in favor of health: the so called pro-health (positive) behaviors, and anti-health (negative) behaviors, also referred to as auto-destructive behaviors. Pro-health behaviors aim to promote health, prevent illness, and facilitate recovery. Anti-health behaviors contribute to health state disturbances and affect one's emotional, physical and psycho-social spheres [2].
\end{abstract}

Purpose. The aim of the study was to characterize health behaviors of amateur mountain biking marathon participants. Methods. The study included 819 participants of amateur mountain biking marathons in Poland, $82.17 \%$ of whom were male and $17.83 \%$ were female. The average age of the participants was $34.85 \pm 8.7$ years. The tools used in the study were Juszczyński's Inventory of Health Behaviors (IHB) and an original survey form.

Results. More than half of the participants $(58.49 \%)$ displayed pro-health behaviors. The study showed a statistically significant correlation between pro-health behaviors and interpersonal status ( $p=0.036)$, having children $(p=0.013)$, age

Conclusions. A majority of mountain biking marathon participants display pro-health behaviors. Promoting pro-health practices and prophylactic measures among people playing sports as a form of recreation should be paid attention to.

Health behaviors may be habitual in their character, displaying a strong pattern of behavior resulting from social processes and cultural influences. They may also be intentional, meaning that certain measures that impact one's health are taken deliberately by that individual. The level of awareness of one's health behaviors is crucial when taking mechanisms of social influence into consideration. It is often the level of awareness of a certain individual that shapes pro- and anti-health behavior [3].

One of the manifestations of pro-health behavior is physical activity. It is often said that amateur sport is directed mainly at increasing one's level of fitness. It is one of the carriers of pro-health values, often includes elements of competition which are fun in nature, and constitute the only objective of physical activity. Amateur sports competitions and tournaments

Correspondence address: Magdalena Gruszczynska, Department of Psychology, School of Health Sciences in Katowice, Chair of Social Sciences and Humanities, Medical University of Silesia, Katowice, Poland,

e-mail: mgruszczynska77@gmail.com

Received: August 13, 2017

Accepted for publication: November 29, 2017

Citation: Gruszczynska M, Bak-Sosnowska M, Plinta R. Health behaviors of amateur mountain bike athletes. Hum Mov. 2018;19(2):60-67; doi: https://doi.org/10.5114/hm.2018.74060. 
have been organized in Poland and all over the world for many years throughout history. Their main characteristics are: large groups and accessibility. They aim at promoting physical activity as a means of a healthy lifestyle, which stands in opposition to the more and more frequent sedentary lifestyle [4]. One type of such recreational events is the mountain biking marathon which has taken place in Poland for many years.

Research shows a positive correlation between moderate physical activity and pro-health habits. People practicing sports pay more attention to good diet, abstaining from substance abuse, regular rest and active pastimes [5-7]. They are typically more optimistic and happy than people who do not practice any sports. Additionally, a sense of optimism correlates with prohealth practices, such as: everyday habits concerning sleep and rest, physical activity, and proper eating habits [8-10].

Mountain biking is gaining popularity. Mountain biking marathons have been organized in Poland for more than 10 years and have been gathering larger and larger numbers of amateur mountain bikers. Participation in such marathons demands proper preparation, which often starts immediately after the end of the previous season. The organizers of the marathon provide information on the dates and places of races a few months before the beginning of a season. The season of mountain biking marathons starts in April and typically lasts until the end of September, consisting of 6-10 races. The participants choose from outlined and marked routes of three different lengths: $25 \mathrm{~km}$ (short-distance), 50km (medium-distance), and $90 \mathrm{~km}$ (long-distance). Those planning on taking part in the marathons usually start their preparations in November of the year preceding the upcoming season. The last two months of the year comprise a preparatory period with training plans full of gym activities, team sports, running, swimming and cycling. In the following three months the training plan becomes more complex and focuses on increasing stamina. It is a pre-start period, in which cycling is the most important form of training. It may be replaced with spinning (as an indoors alternative to cycling available in fitness clubs), supplementary gym exercises, swimming and running. This period aims to prepare the body for prolonged physical effort once the season starts. The training volume may reach 10-20 hours per week in more ambitious amateurs. The last period is the season itself, the most important element of which is participation in the marathons.

There are many mountain biking marathon participants, who organize their everyday lives with regard to the marathon preparations including a detailed training plan for each day and a strict diet counting the amount of kcals and nutrients in their meals. However, there are also people who treat taking part in the marathons as a pastime. Those who start in marathons vary greatly in terms of age, education, and material status.

Literature on the subject rarely analyzes health behaviors of amateur mountain bikers. Additionally, researchers differ in their opinions on health behaviors of amateur sportsmen. A significant amount of attention is devoted to issues related to proper dietary habits, while other determinants of health behaviors are often neglected in research. Taking into consideration that physical activity is one of the primary health behaviors, one could assume that people who train for mountain biking marathons will display other pro-health practices. It may be observed, however, that practicing sports often does not go hand in hand with other pro-health behaviors, such as a healthy diet, transportation safety, abstaining from substance abuse, and regular medical checkups.

The aim of this study was to characterize the health behaviors of participants of amateur mountain bike marathons in Poland.

\section{Material and methods}

The study encompassed 819 participants of amateur mountain biking marathons from various regions of Poland. The study was carried out in January 2014. It was used as cross-sectional research. The participation was voluntary and anonymous. The participants were informed about the aim and the form of the study and asked to fill in the questionnaires on their own. Each questionnaire included its own set of instructions and there was no time limit for providing answers to the questions.

The tools used in the study were:

- Juszczyński's Inventory of Health Behaviors (IHB): Aims to examine health behaviors of a given individual. Includes 24 statements describing various health-related behaviors which belong to four different categories: eating habits, prophylactic measures, positive attitude, and health practices. The participant is asked to rate the statement according to Likert's 1-5 scale, 1 referring to "almost never" and 5 to "almost always". The maximum possible score is 100 . The provided answer depicts the participant's adherence to the given statement in the past year. The results of the questionnaire are two-fold: partial - displaying health behaviors of a person in separate categories, and general - displaying the frequency of all health behaviors. 


\section{HUMAN MOVEMENT}

M. Gruszczynska, M. Bak-Sosnowska, R. Plinta, Health behaviors of amateur mountain bike athletes

- Original survey form: the survey form included two sections: demographics/particulars (i.e. age, body mass, height, interpersonal status, place of residence), and closed (forced-choice) questions relating to the specifics of the sports discipline practiced and health behaviors not listed in IHB. Based on the responses regarding actual body mass and height, BMI was determined using the formula BMI = body mass $(\mathrm{kg}) /$ body height $(\mathrm{m})^{2}$.

\section{Statistical analysis}

Data analysis was conducted using the STATISTICA software package (STATISTICA 10 Copyright $\odot$ StatSoft, 2011). In all forms and at all stages of the statistical analysis $\alpha=0.05$ was chosen as the significance level. The Shapiro-Wilk test was applied to test the normality of distribution. As the results of much of the test did not comply with normal distribution, nonparametric tests were applied: Mann-Whitney $U$ test, Pearson's chi-squared test, Kruskal-Wallis one-way analysis of variance, and Spearman's rank correlation coefficient were used in one-factor analysis.

\section{Ethical approval}

The research related to human use has been complied with all the relevant national regulations and institutional policies, has followed the tenets of the Declaration of Helsinki, and has been approved by the authors' institutional review board or an equivalent committee.

The study was approved by the commission of bioethics at the Medical University of Silesia on the basis of resolution KNW/0022/KB/258/13 from December $10^{\text {th }}, 2013$.

\section{Informed consent}

Informed consent has been obtained from all individuals included in this study.

\section{Results}

The average age of the participants was $34.85 \pm$ 8.7 years. Average BMI of the participants was $23.54 \pm$ $2.73 \mathrm{~kg} / \mathrm{m}^{2}$ which falls into the normal weight range (18.5-24.9 BMI) according to World Health Organization norms. The average experience in taking part in mountain biking marathons was $4.36 \pm 2.59$ years, while the average time devoted to training per week was $7.89 \pm 4.99$ hours. Characteristics of the group are shown in Table 1.

The majority of participants took part in the medium-distance marathons (50\%). The short-distance marathons were chosen by a smaller number of participants (31\%), while the long-distance marathons were the least popular among the participants (19\%). The majority of the participants were male $(82.17 \%)$, lived in a city with a population over 100,000 people $(49.82 \%)$, were married or stayed in an informal relationship (69.6\%), did not have children (51.89\%), had a higher level of education (69.23\%), and were employed under an employment contract (53.96\%).

The results achieved by the participants were analyzed for each category in the Inventory as well as the overall total. The average general result of the Inventory was $81.74 \pm 11.63$ points $(0-100)$. Health behaviors among the participants is shown in Table 2.

The general results of the Inventory of Health Behaviors were transformed to a 10-point scale based on the instructions of the authors of the questionnaire. The results were then dichotomized for the sake of sub-

Table 1. Characteristics of the group

\begin{tabular}{lcccccc}
\hline Variable & N & Mean & Median & Min & Max & Standard deviation \\
\hline Age & 819 & 34.85 & 35.00 & 20.00 & 50.00 & 8.70 \\
BMI & 819 & 23.54 & 23.38 & 16.66 & 33.91 & 2.73 \\
Participation in MTB marathons (years) & 819 & 4.36 & 3.00 & 2.00 & 12.00 & 2.59 \\
Time devoted to training (hours per week) & 819 & 7.89 & 7.00 & 0.00 & 40.00 & 4.99 \\
\hline
\end{tabular}

Table 2. Health behaviors among the participants

\begin{tabular}{lcccccc}
\hline Variable & N & Mean & Median & Min. & Max. & Standard deviation \\
\hline Proper eating habits & 819 & 21.31 & 22.00 & 7.00 & 30.00 & 4.60 \\
Positive attitude & 819 & 21.00 & 21.00 & 9.00 & 30.00 & 3.41 \\
Health practices & 819 & 19.97 & 20.00 & 10.00 & 30.00 & 3.37 \\
Prophylactic measures & 819 & 19.46 & 19.00 & 6.00 & 30.00 & 4.25 \\
\hline
\end{tabular}


Table 3. Relationship between IZZ and qualitative variables

\begin{tabular}{llccccc}
\hline \multirow{2}{*}{ Variable } & & \multicolumn{2}{c}{ Pro-health behaviors } & \multicolumn{2}{c}{ Anti-health behaviors } & Test chi $^{2}$ \\
\cline { 3 - 6 } & & $\mathrm{n}$ & $\%$ & $\mathrm{n}$ & $\%$ & \\
\hline \multirow{2}{*}{ Partnership situation } & Partner & 347 & 60,88 & 223 & 39,12 & $\boldsymbol{p}=\mathbf{0 . 0 3 6}$ \\
& No partner & 132 & 53,01 & 117 & 46,99 & 37,06 \\
Children & Yes & 248 & 62,94 & 146 & $\mathbf{p}=\mathbf{0 . 0 1 3}$ \\
& No & 231 & 54,35 & 194 & 45,65 & \\
\hline
\end{tabular}

$p$ - probability value

Table 4. Relationship between IZZ and quantitative analysis

\begin{tabular}{lccccc}
\hline \multirow{2}{*}{ Variable } & \multicolumn{2}{c}{ Pro-health behaviors } & \multicolumn{2}{c}{ Anti-health behaviors } & \multirow{2}{*}{ Mann-Whitney U test } \\
\cline { 2 - 5 } & mean & standard deviation & mean & standard deviation & \\
\hline Age & 35.44 & 8.91 & 34.03 & 8.34 & $\boldsymbol{p}=\mathbf{0 . 0 3 1}$ \\
$\begin{array}{l}\text { Time devoted to training } \\
\text { (hours per week) }\end{array}$ & 8.34 & 5.20 & 7.25 & 4.61 & $\boldsymbol{p}=\mathbf{0 . 0 0 3}$ \\
\hline
\end{tabular}

$p$ - probability value

Table.5 Logistic regression analysis of dependent variables' impact on pro-health behaviors

\begin{tabular}{lcccc}
\hline Dependent variable & Odds ratio & $-95 \%$ CI & $+95 \%$ CI & Wald test \\
\hline Age & 1.029 & 1.012 & 1.047 & $\boldsymbol{p}=\mathbf{0 . 0 0 1}$ \\
Time devoted to training (hours per week) & 1.050 & 1.018 & 1.083 & $\boldsymbol{p}=\mathbf{0 . 0 0 2}$ \\
\hline
\end{tabular}

CI - confidence interval, $p$ - probability value

sequent analysis in order to obtain the low results (1-5 points), and high results (6-10 points). More than half of the participants (58.49\%) achieved high results for pro-health behaviors.

For the sake of detailed analysis of health behaviors, the results achieved by means of the Inventory were juxtaposed with the results of the survey. More than half of the participants followed a diet suiting the needs of the sport they practice $(59.22 \%)$ and ate fast food less than once in a week (54.21\%). A large majority of the participants $(89.50 \%)$ declared that they had never smoked. More than a half of the participants (63.61\%) declared that they drank medium and low percentage alcohol once a week or less than once a week, while a vast majority of the participants (98.5\%) never drank high percentage alcohol or drank it less than once a week. Taking dietary supplements for athletic performance was reported by $64.83 \%$ of the participants. At the same time, more than a half (51.04\%) had never consumed energy products. A large majority of the participants (99.39\%) had never used illegal doping substances.
One-factor analysis showed statistically significant correlation between pro-health behaviors and one's interpersonal status, as well as having children (Table 3). However, no statistically significant differences were shown between genders, places of residence, education, and preferred marathon distance.

In terms of qualitative variables, a statistically significant difference was found between participants displaying pro-health and anti-health behaviors in relation to their age and time devoted to training (Table 4). No statistically significant differences were found between participants' BMI and their marathon experience.

In order to determine the predictors of the occurrence of pro-health behaviors among participants, a logistic regression analysis was carried out. The logistic regression analysis showed that:

- with each year of the life the odds of pro-health behaviors increased by $2.9 \%$;

- with every additional hour of training per week the odds of pro-health behaviors increased by $5 \%$ (Table5). 
M. Gruszczynska, M. Bak-Sosnowska, R. Plinta, Health behaviors of amateur mountain bike athletes

\section{Discussion}

Reports on health behaviors of recreational athletes are varied. Regular physical activity is often associated with the introduction of healthy behaviors and elimination of bad habits [10]. On the other hand, some authors suggest that there is a relationship between physical activity and increased risk-taking behavior (smoking, alcohol abuse) [11-12]. However, many of these studies involve the period of adolescence and early youth, which may slightly skew the results for people playing sports at any age.

The study carried out by the authors included a broad cross-sectional age group (20-50 years), which allows for a wider interpretation of the results. The group consisting of mountain biking marathon participants largely manifested pro-health behavior. The general result obtained is comparable with a normative adult group in the Polish population [13].

Lipowski et al. [14] examined $127 \mathrm{PE}$ teachers (58 women and 69 men) aged 23-57 with the use of the Inventory of Health Behaviors. Results showed that the examined teachers had an average level of pro-health behaviors ( $80.2 \pm 10.1 \mathrm{pts})$ as well as average results in each of the four categories of health behaviors. The results are surprising as physically active people who are teachers, and therefore role models for their students, are expected to care for health on many levels, not only when sport is considered. In this case, it can be assumed that physical activity is a piece of one's lifestyle which does not always coexist with other health behaviors.

The highest results regarding proper eating habits obtained by mountain biking marathon participants point to the fact that involvement in competitions and training coexist with healthy nutrition, which is particularly important in practicing sports of high intensity. Most of the participants reported that they tried to adjust their diet to the type of sport they practice. The participants not only paid attention to healthy nutrition, but also tried to supplement micro- and macro-elements they were losing while training and competing. Management of proper nutrients prevents the weakening of the immune system of the body, which is fatigued following high intensity activities and influences its capabilities [15].

At the same time, the examined group achieved high results in the field of positive attitude which includes: avoiding maximally strong emotions, stressors, tensions and depressing situations. Respondents reported that they often use measures for improving psychological well-being such as: relaxation, leisure, and physical activity. Additionally, they have a high perception of their ability to cope with stress. This result is in line with other studies which point to the strong correlation between practicing sports and positive attitude. Guszkowska [16] examined three groups of women who participated in aerobics classes. The first group consisted of women aged 20-27 (practicing aerobics for a long time and preparing for a fitness instructor exam). The second and third groups consisted of women who had been practicing aerobics from one to three months and participating in classes once a week for 60 minutes (group A) or three times a week for 45 minutes (group B). The age of the participants ranged from 20-40 years in group A and from 18-44 years in group B. Based on the research, it was concluded that physical exercise causes a significant decrease in the level of anxiety of a person performing physical exercise, and that systematic practice leads to a significant improvement in mood.

At the same time, Lipowski's research [8] points out that people who practice sports regularly are more optimistic and happy compared to people who do not practice any kind of sport. The author analyzed 532 people practicing different kinds of sports (147 women, 385 men). A control group consisted of 697 people who were physically inactive (264 women, $435 \mathrm{men}$ ). In women, a sense of optimism coexisted with pro-health practices, such as daily habits concerning sleep and rest or physical activity. The group of mountain bikers in the study showed slightly lower results in the scope of prophylactic measures, including regular checkups. However, those results did not differ much from those of an average adult [13]. Promotion of this category of health behavior seems essential, considering that participation in mountain biking marathons should coexist with regular health screenings to address negative effects of excessive physical activity. Equally relevant is the fact that the organizers of marathons do not require doctor's certificates stating that the participant's health is sufficient to allow him/her to take part in the competition. The participants are simply required to provide a statement that they are in good health.

It is important to draw attention to the fact that the majority of the participants (90\%) reported that they had never smoked cigarettes, which has been proven to have a negative impact on the respiratory and circulatory functions. Likewise, the reported intake of alcoholic was also at low levels. In contrast to the results, it is worth quoting research conducted in 2005-2006 among NCCA participants. This research showed significant differences in alcohol consumption between professional and amateur sportspeople (418 men and 475 women). The differences pertained 
mainly to men. Sportsmen associated with the NCCA consumed alcohol in large quantities more often: a behavior known as harmful or binge drinking. There were no significant differences among women. In the group of students associated with university sport clubs, $78 \%$ reported consuming alcohol and $92 \%$ of them consumed it excessively. Researchers, trying to find the cause of alcohol intake in sportsmen, pointed to the following factors: stress, elevated levels of anxiety, depressed mood connected with failure, and strong tendency for new experiences [11].

Use of dietary supplements by sportspeople is popular among professionals and is becoming more widespread among amateurs. In the research group, over half of the participants declared using dietary supplements [17-18].

Opinions on the benefits and legitimacy of the use of such substances by amateurs vary. Some scientists point to the advantages of taking dietary supplements, especially by those who perform intense physical activity that prevents them from getting their daily required vitamins from food only. The results of the research conducted by Tsitsimpikou et al. [19] on dietary supplement usage by people who exercise recreationally at the gym is disturbing. The research was conducted in Greece and included 329 participants, 180 of whom were men and 149 women. The average age of the participants was 30 years old. $41 \%$ of the participants used supplements, however, only $17 \%$ of this group consulted with a doctor or nutritionist before taking supplements. The supplements taken by the participants were laboratory tested. Only $30 \%$ of the participants were confident in how to use the supplements properly, including which substances were amongst the ingredients. During laboratory tests, synthetic anabolic steroids were discovered in two products. Neither of them had this information presented on the label. Bearing this in mind, it is worth considering reasonable intake of supplements, preferably under medical supervision.

The answers to the question regarding the use of illegal performance-enhancing drugs may also be disturbing. $1 \%$ of the participants declared using such substances. It is worth noting that any question regarding the use of illegal substances carries a risk of getting answers that may not be reliable. Admitting to illegal practices, despite the anonymity of the research, can be risky and the real scale of substance use may be higher. The commonness of the phenomenon of doping among professional bikers, who often are role models for amateurs, may cause increased use of illegal performance-enhancing substances. The use of such substances by amateurs suggests that having the highest score in the marathon becomes the main objective of practicing, which does not coincide with the aims of amateur sports and certainly does not coincide with its pro-health values. Such behavior may be harmful to the participant's health and wellbeing. When analyzing health behaviors, it is also crucial to consider the factors which determine such actions. Great importance is given to gender when it comes to health behaviors. Women are considered to take care of their health more often than men [20-22].

The results of the study carried out by the authors did not show significant differences in the occurrence of pro-health behaviors among men and women. It can be assumed that in such a specific group, consisting of people who are connected by practicing pro-health sports, men are as equally motivated as women. Similar results were obtained by Boguszewski et al. [5] who examined a group of 110 basketball players (42 women and 68 men) with the use of the Inventory of Health Behaviors. The general result of the IHB was average (77.12) and, at the same time, no differences between men and women were found in the scope of presented pro- and anti-health behaviors.

The results of the study carried out by the authors also showed that people in relationships and people having children are more prone to taking care of their health. Researchers point to the significant role of parents in acquiring behaviors connected with an active or sedentary lifestyle in children. Parents who practice sports and spend their time actively are the best role models for an active and healthy lifestyle. As it was mentioned in the introduction, the process of socialization has an impact on taking pro-health actions. It can be noted that the examined participants follow a healthy lifestyle as an effect of their own experience in the process of socialization. Moreover, having children and/or a partner may be motivating for taking care of one's health. Situations in social relationships also have an impact on pro-health behavior. Members of family and friends can influence the character of healthy habits of an individual [23].

The essential factor which influences pro-health behaviors is also the age of the respondents. Older people tend to show a greater concern for their health which seems to be explained not only by their more extensive level of knowledge and life experience, but also potential health problems arising due to their advancing age and the need for avoiding or alleviating them.

Taking part in mountain biking marathons requires physical preparation. The number of hours devoted to training is often reflected in the results achieved in the competition, which, in turn, may contribute to the satisfaction of achieving continually better results. 
M. Gruszczynska, M. Bak-Sosnowska, R. Plinta, Health behaviors of amateur mountain bike athletes

For many, however, top positions are not the most important aspect of participating in mountain biking marathons. Instead, it is the participation itself, the joy of a bike ride and of being able to cross the finish line. An additional positive effect of the amount of time devoted to training is the increased occurrence of pro-health behaviors in the examined group. Mountain bikers who devoted more time to training adopted pro-health behaviors to a larger degree than those who trained less. Such results suggest that mountain biking is not just a way of spending free time or meeting the need of fulfillment by competing with others, but a broadly understood lifestyle which allows one to stay fit and healthy.

After analyzing results from this research study, some limitations must be acknowledged. As answers are coming strictly from volunteers, the group may not be representative. Additionally, the test used to measure health behaviors is based on subjective answers from the participants and is therefore only able to measure health behaviors in an indirect way.

\section{Conclusions}

In summary, more than half of the mountain biking marathon participants displayed pro-health behaviors. More than half of the mountain bikers had proper eating habits, healthy diets, and didn't use stimulants. More importantly, part of the group did not take prophylactic measures, and this could have a negative influence on their health. Pro-health values should lay at the bottom of amateur sport. Correctly understood and practiced amateur sport is an alternative to a sedentary lifestyle that is becoming increasingly more common for modern civilization. It is important to draw attention to social campaigns which promote healthy lifestyles and prevent the socalled diseases of affluence. The majority of the participants of mountain biking marathons displayed prohealth behaviors. The promotion of a healthy lifestyle including health practices and preventive measures among people who practice sports recreationally should be paid attention to.

\section{Disclosure statement}

No author has any financial interest or received any financial benefit from this research.

\section{Conflict of interest}

The authors state no conflict of interest.

\section{References}

1. Gochman DS, editor. Health behavior: Emerging research perspectives. New York: Plenum Press; 1988.

2. Heszen I, Sęk H. Health psychology [Psychologia zdrowia, in Polish]. Warszawa: PWN; 2007.

3. Sheeran P, Gollwitzer PM, Bargh JA. Nonconscious processes and health. Health Psychol. 2013;32(5):460473; doi: 10.1037/a0029203.

4. Stewart RAH, Held C, Hadziosmanovic N, Armstrong PW, Cannon CP, Granger CB, et al. Physical Activity and Morality in Patients With Stabile Coronary Heart Disease. J Am Coll Cardiol. 2017;70(14):1689-1700; doi: 10.1016/j.jacc.2017.08.017.

5. Boguszewski D, Andersz N, Janicka M, Mrozek N, Nowakowski P, Adamczyk J, Assessment of healthrelated behaviors of women and men practicing basketball [Ocena zachowań zdrowotnych kobiet i mężczyzn uprawiających koszykówkę, in Polish]. J Health Sci. 2014;4(5):41-46.

6. Litwic-Kamińska K, Izdebski P. The concept, subjective health assessment, health behaviours and physical activity level in early adulthood [Pojęcie i samoocena zdrowia oraz zachowania zdrowotne a poziom aktywności fizycznej w okresie wczesnej dorosłości, in Polish]. Med Sport. 2012;3(4):167-178.

7. Delisle T, Werch CE, Wong AH, Bian H, Weiler R. Relationship between frequency and intensity of physical activity and health behaviours of adolescents. J Sch Health. 2010;80(3):134-140; doi: 10.1111/j.1746-1561. 2009.00477.x.

8. Lipowski M. Level of optimism and health behavior in athletes. Med Sci Monit. 2012;18(1):39-43; doi: 10.12659/ MSM.882200.

9. Durkalec-Michalski K, Suliburska J, Jeszka J. The assessment of nutritional status and eating habits in a selected group of rowers [Ocena stanu odżywienia i nawyków żywieniowych wybranej grupy zawodników uprawiających wioślarstwo, in Polish]. Bromat Chem Toksykol. 2011;44(3):262-270.

10. Frączek B, Brzozowska E, Morawska M. Assessment of nutritional habits in athletes practicing team sports in view of the Swiss food pyramid recommendations [Ocena zachowań żywieniowych zawodników trenujących gry zespołowe w świetle rekomendacji piramidy żywieniowej sportowców, in Polish]. Prob Hig Epidemiol. 2013;94(2):280-285.

11. Yusko DA, Buckmann JF, White HR, Pandina RJ. Alcohol, tobacco, illicit drugs and performance enhancers: a comparison of use by college student athletes and nonathletes. J Am Coll Health. 2008;57(3):282-290; doi: 10.3200/JACH.57.3.281-290.

12. Mayolas-Pi C, Simon-Grima J, Penarrubia-Lozano C, Manguia-Izquierdo D, Moliner-Urdiales D, Legaz-Arrese $\mathrm{A}$. Exercise addiction risk and health in male and female amateur endurance cyclists. J Behav Addict. 2017;6(1):74-83; doi: 10.1556/2006.6.2017.018. 
13. Juczyński Z. Measurement tools in promotion and health psychology [Narzędzia pomiaru w promocji i psychologii zdrowia, in Polish]. Warszawa: Pracownia Testów Psychologicznych; 2009.

14. Lipowski M., Szczepańska-Klunder Ż. Health behavior of physical education teachers. [Zachowania zdrowotne nauczycieli wychowania fizycznego, in Polish]. In: Jastrzębski Z, editor. Theory and practice of physical education and sport [Teoria i praktyka wychowania fizycznego i sportu, in Polish]. T 1. Łódź: University of Sport in Łódź; 2013; 9-26.

15. Jurkowski M, Handzlik M, Mikołajczyk A, Peterko D. Influence of some dietary components on immune system activity during intensive physical effort [Wpływ wybranych składników diety na funkcje układu odpornościowego w czasie intensywnego wysiłku fizycznego, in Polish]. Med Sport 2008,3(6):133-148.

16. Guszkowska M. The effect of regular aerobic excercises on emotional states in women [Wpływ regularnych ćwiczeń aerobiku na stany emocjonalne kobiet, in Polish]. Med Sport. 2006;3(6):163-168.

17. Abo Ali EA, Elgmal HH. Use of dietary supplements among gym trainees in Tanta city, Egypt. J Egypt Public Health Assoc. 2016;91(4):185-191; doi: 10.1097/01. EPX.0000511736.22873.57.

18. Alshammari SA, AlShowair MA, AlRuhaim A. Use of hormones and nutritional supplements among gyms' attendees in Riyadh. J Fam Community Med. 2017; 24(1):6-12; doi: 10.4103/2230-8229.197175.

19. Tsitsimpikou C, Chrisostomou N, Papalexis P, Tsarouhas K, Tsatsakis A, Jamurtas A. The use of nutritional supplements among recreational athletes in Athens, Greece. Int J Sport Nutr Exerc Metab. 2011;21(5):377384; doi: 10.1123/ijsnem.21.5.377.

20. Binkowska-Bury M, Iwanowicz-Palus G, Kruk W, Perenc L, Mazur A, Filip R, Januszewicz P. Pro-health behaviours - a sense of coherence as the key to a healthy in rural areas? Ann Agric Environ Med. 2016;23(2): 345-349; doi: 10.5604/12321966.1203903.

21. Ogińska-Bulik N (ed.). Risky and harmful behavior for health [Zachowania ryzykowne i szkodliwe dla zdrowia, in Polish]. Łódź: Akademia Humanistyczno-Ekonomiczna; 2010.

22. Królikowska S. Inequalities in health status between men and women in the context of sex and gender [Nierówności w stanie zdrowia między kobietami a mężczyznami w kontekście płci biologicznej oraz społecznokulturowej, in Polish]. Ann Univ Lodz Sociol 2011;39: 33-52.

23. Ślusarska B, Dobrowolska B, Zarzycka D. Metatheoretical context of health behavior in health paradigms [Metateoretyczny kontekst zachowań zdrowotnych w paradygmatach zdrowia, in Polish]. Probl Hig Epidemiol. 2013;94(4):667-674. 